ACTA MYCOLOGICA

Vol. 45 (1): 17-25

2010
Dedicated to Professor Barbara Gumińska on the occasion of her eighty-fifth birthday

\title{
Ambispora gerdemannii and Glomus badium, two species of arbuscular fungi (Glomeromycota) new for Europe and Poland, respectively
}

\author{
${ }^{1}$ JANUSZ BŁASZKOWSKI, ${ }^{1}$ BEATA CZERNIAWSKA, ${ }^{1}$ SŁAWOMIR KOWALCZYK, \\ ${ }^{2}$ KATARZYNA TURNAU and ${ }^{3}$ SZYMON ZUBEK
}

\author{
${ }^{1}$ Department of Plant Protection, West Pomeranian University of Technology \\ Słowackiego 17, PL-71-434 Szczecin, janusz.blaszkowski@zut.edu.pl \\ ${ }^{2}$ Department of Ecological Microbiology, Institute of Environmental Sciences \\ Jagiellonian University, Gronostajowa 7, PL-30-387 Kraków, katarzyna.turnau@uj.edu.pl \\ ${ }^{3}$ Laboratory of Mycology, Institute of Botany, Jagiellonian University \\ Lubicz 46, PL-31-512 Kraków, szymon.zubek@uj.edu.pl
}

Błaszkowski J., Czerniawska B., Kowalczyk S., Turnau K., Zubek S.: Ambispora gerdemannii and Glomus badium, two species of arbuscular fungi (Glomeromycota) new for Europe and Poland, respectively. Acta Mycol. 45 (1): 17-25, 2010.

Morphological characters of spores, as well as sporocarps and spores of Ambispora gerdemannii and Glomus badium, respectively, arbuscular fungi of the phylum Glomeromycota, are described and illustrated. Additionally, the known distribution of these species in both Poland and the other regions of the world is presented. Ambispora gerdemannii was not earlier reported from Europe, and G. badium is a new fungus for Poland.

Key words: Glomeromycota, occurrence, distribution

\section{INTRODUCTION}

Analysis of collections of arbuscular-mycorrhizal fungi made over the last 27 years in Poland and other regions of the world included two unrecorded species, i. e., Ambispora gerdemannii (S.L. Rose, B.A. Daniels et Trappe) Spain, Oehl et Sieverd. and Glomus badium Oehl, Redecker et Sieverd. The former fungus has not so far been reported from Europe, and the latter species has not been reported to occur in Poland to date.

The aims of this paper are to describe and illustrate these species and present their distribution in both Poland and the world. 


\section{MATERIALS AND METHODS}

The methods of collection of soil samples, establishment of trap and one-species cultures, growth conditions, isolation and preparation of spores and the determination of properties of their subcellular structure, as well as the terminology of spore structure and colours, the nomenclature of plants and fungi, and the authors of the fungal names used are as those presented previously (Błaszkowski, Czerniawska 2005). Microphotographs were recorded on a Sony 3CDD color video camera coupled to an Olympus BX 50 compound microscope equipped with Nomarski differential interference contrast optics.

Voucher specimens were mounted in polyvinyl alcohol/lactic acid/glycerol (PVLG; Omar, Bollan and Heather 1979) and a mixture of PVLG and Melzer's reagent (1:1, $\mathrm{v} / \mathrm{v}$ ) on slides and deposited in the Department of Plant Pathology (DPP).

Colour microphotographs of spores of Am. gerdemannii and G. badium can be viewed at the URL http://www.agro.ar.szczecin.pl/ jblaszkowski/.

\section{DESCRIPTIONS OF THE SPECIES}

Ambispora gerdemannii (S.L. Rose, B.A. Daniels et Trappe) C. Walker, Vestberg et Schuessler

Spores formed singly in the soil; arise blastically at the tip of a hyphal branch (pedicel) on the neck of a sporiferous saccule (Figs 1 and 8). Spores pale yellow (4A3) to maize yellow (4A6), globose to subglobose, $(150-) 210(-250) \mu \mathrm{m}$ diam, sometimes ovoid, 150-190 $\times 210-250 \mu \mathrm{m}$. Subcellular structure of spores consists of a spore wall and two inner germination walls (Figs 3-6 and 8). Spore wall composed of three layers (layers 1-3). Layer 1, forming the spore surface, evanescent, pale yellow (4A3) to maize yellow (4A6), (1.7-)3.3(-5.6) $\mu \mathrm{m}$ thick when intact, usually with deep fissures due to sloughing with age (Figs 1 and 2). Layer 2 semi-flexible, smooth, hyaline (1.2-)2.5(-3.7) $\mu \mathrm{m}$ thick, continuous with the wall of the pedicel (Figs 3-6 and 8). Layer 3 flexible to semi-flexible, hyaline, $0.5-1.0 \mu \mathrm{m}$ thick, usually tightly adherent to the lower surface of layer 2 and, hence, difficult to see (Figs 3-5 and 8). Germination wall 1 comprises two fragile, smooth, hyaline layers (layers 1 and 2), (0.5-)1.1(-1.6) $\mu \mathrm{m}$ and (0.6-)1.4(-2.1) $\mu \mathrm{m}$ thick, respectively, usually tightly adherent to one another and readily cracking to form line slits or polygonal pieces in crushed spores (Figs 3-8). Germination wall 2 consists of three smooth, hyaline layers (layers 1-3; Figs 3-5 and 8). Layer 1 flexible to semi-flexible, $0.5-0.8 \mu \mathrm{m}$ thick, always tightly adherent to layer 2 and, thereby, very difficult to observe (Figs 3-5). Layer 2 semi-flexible, finely laminate, hyaline, (1.7-)2.8(-4.1) $\mu \mathrm{m}$ thick (Figs 3-5 and 8). Layer 3 flexible to semiflexible, 0.5-0.8 $\mu \mathrm{m}$ thick (Figs 3-5), rarely separating from layer 2. In Melzer's reagent, only spore wall layer 1 stains orange (6A6) to pastel red (8C5; Fig. 5). Pedicel $10-15 \mu \mathrm{m}$ long, $15-27 \mu \mathrm{m}$ wide at the spore base, positioned 80-120 $\mu \mathrm{m}$ from the base of the sporiferous saccule, consisting of a hyaline wall continuous with the wall of the saccule neck, the spore wall, and layer 1 of germination wall 1 (Fig. 8). Sporiferous saccule hyaline to yellowish white (4A2), globose to subglobose, (185-)200(-275) $\mu \mathrm{m}$ 

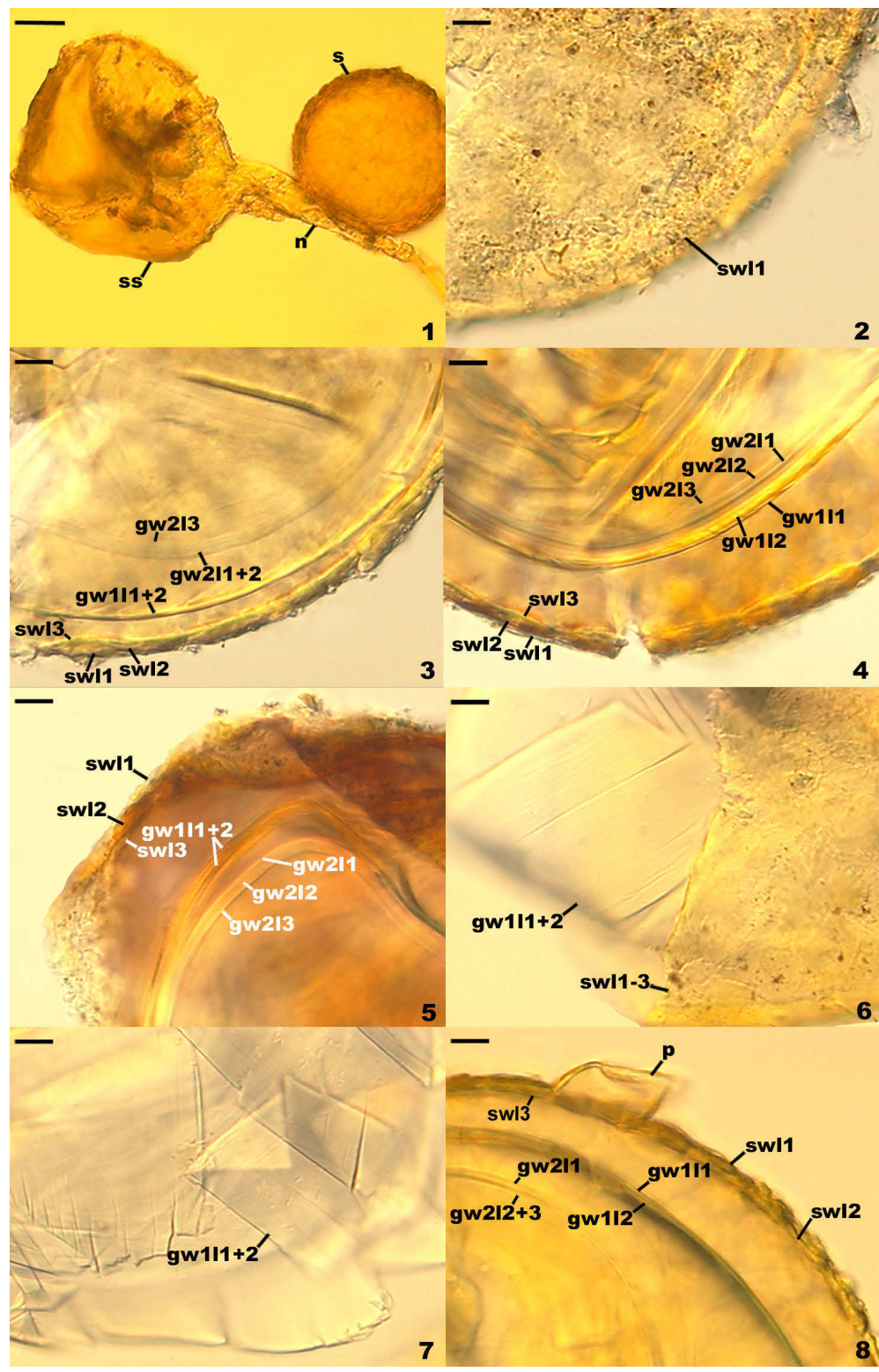

Figs 1-8. Ambispora gerdemannii. 1. Spore (sp) associated with the neck (n) of sporiferous saccule (ss). 2. Partly deteriorated spore wall layer 1 (swl1). 3-5. Spore wall layers 1-3 (swl1-3), layers 1 and 2 of germination wall 1 (gw1l1 +2), and layers 1-3 of germination wall 2 (gw211-3). 6. Spore wall layers 1-3 (swl1-3) and layers 1 and 2 of germination wall $1(\mathrm{gw} 111+2)$ with line splits in slightly crushed spore. 7. Disintegrated layers 1 and 2 of germination wall $1(\mathrm{gw} 111+2)$ in vigorously crushed spore. 8. Spore wall layers 1-3 (swl1-3), layers 1 and 2 of germination wall $1(\mathrm{gw} 111+2)$, layers 1-3 of germination wall $2(\mathrm{gw} 211-3)$, and pedicel (p) with a wall continuous with spore wall layer 2. Fig. 1, spore in lactic acid. Figs 2-4 and 6-8, spores crushed in PVLG. Fig. 5, spore crushed in PVLG+Melzer's reagent. Fig. 1, bright field microscopy; Figs 2-8, differential interference contrast. Scale bars for Fig. $1=50 \mu \mathrm{m}$, for Figs 2-8 $=10 \mu \mathrm{m}$. 

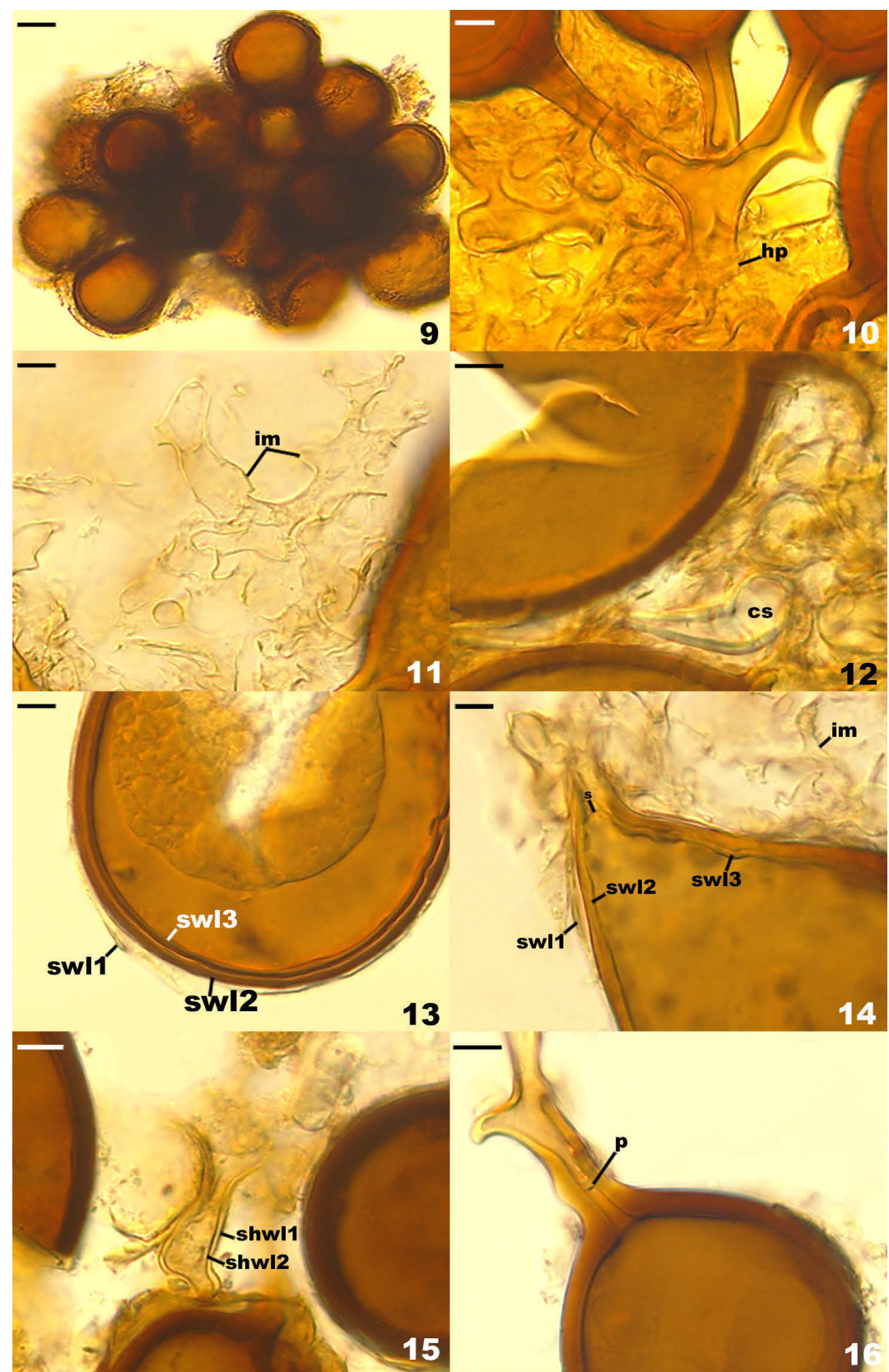

Figs 9-16. Glomus badium. 9. Sporocarp. 10. Hyphal plexus (hp). 11. Interspore mycelium (im). 12. Cystidium-like structure (cs). 13. Spore wall layers 1-3 (swl1-3). 14. Spore wall layers 1-3 and interspore mycelium (im); septum (s) of the subtending hypha formed by spore wall layer 3 is indicated. 15. Subtending hyphal wall layers 1 and 2 (shwl-2). 16. Plug (p) in the lumen of subtending hypha. Figs 9 and 11-16, spores crushed in PVLG. Fig. 10, spore crushed in PVLG+Melzer's reagent. Figs 9-16, differential interference contrast. Scale bars for Fig. $9=20 \mu \mathrm{m}$, for Figs $10-16=10 \mu \mathrm{m}$. 
diam, occasionally ovoid, $160-200 \times 210-260 \mu \mathrm{m}$, formed at the end of a funnelshaped neck (Fig. 1). Wall of sporiferous saccule semi-flexible, semi-permanent, hyaline to yellowish white (4A2), 3.5-8.8 $\mu \mathrm{m}$ thick, smooth in young specimens, roughened because of a patchy sloughing of its outer surface, composed of two to three tightly adherent layers, usually difficult to observe. Saccule neck hyaline to yellowish white (4A2), 200-250 $\mu \mathrm{m}$ long, 30-45 $\mu \mathrm{m}$ wide at the base of the saccule, 20-25 $\mu \mathrm{m}$ wide at the spore base, then gradually tapering up to 8-10 $\mu \mathrm{m}$ wide.

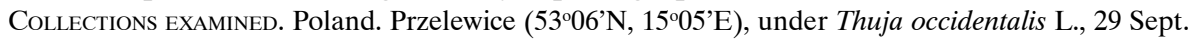
1989, Btaszkowski J. 1722 and 1783-1801 (DPP); Truskaw (52 $\left.18^{\prime} \mathrm{N}, 20^{\circ} 46^{\prime} \mathrm{E}\right)$, from the root zone of Juniperus communis L., 9 Aug. 1990, Btaszkowski J. 1802-1804 (DPP); Trzciel (52²2’N, 1552'E), among roots of Equisetum arvense L., 13 Aug. 2004, Btaszkowski J. 1805-1806 (DPP); Romanówek (52¹7’N, 15²2'E), from under Achillea millefolium L. and Hypericum perforatum L., 13 Aug. 2004, Btaszk. J., s.n. (DPP); Lubrza (52 $\left.18^{\prime} \mathrm{N}, 15^{\circ} 27^{\prime} \mathrm{E}\right)$, under H. perforatum, 13 Aug. 2004, Btaszk. J. s.n. (DPP); Tatra Mountains, among roots of Campanula polymorpha Witasek, Cardaminopsis neglecta (Schul.) Hayek, Cerastium tatrae Borbás, Knautia kitaibelii (Schult.) Borbás, Leucanthemum waldsteinii (Sch. Bip.) Pouzar, Melampyrum herbichii Woł., Sesleria tatrae (Degen) Deyl, and Thymus sp., Błaszkowski J. 2634-2643 (DPP).

Distribution AND habitat. In Poland, spores of Ambispora gerdemannii were found in 19 samples of roots and rhizosphere soils of 14 species of uncultivated plants. None of the almost 1500 root and soil mixtures coming from cultivated sites of Poland contained spores of this fungus.

The average abundance of $\mathrm{Am}$. gerdemannii spores in the samples examined was 4.7 and ranged from 1 to 29 in $100 \mathrm{~g}$ dry soil. The proportion of spores of this species in spore populations of all the arbuscular fungi recovered averaged $11.8 \%$ in a range of 2.1-66.7\%. The average abundance of species of arbuscular fungi in samples in which spores of Am. gerdemannii occurred was 2.7 and ranged from 1 to 6 in $100 \mathrm{~g}$ dry soil.

The arbuscular fungi accompanying Am. gerdemannii in the field were Acaulospora bireticulata F.M. Rothwell et Trappe, A. capsicula Błaszk., A. koskei Błaszk., A. lacunosa J.B. Morton, A. paulinae Błaszk., Ar. trappei (R.N. Ames et Linderman) J.B. Morton et D. Redecker, Entrophospora infrequens (I.R. Hall) R.N. Ames et R.W. Schneid., G. caledonium (Nicol. et Gerd.) Trappe et Gerd., G. claroideum N.C. Schenck et S.M. Sm., G. constrictum Trappe, G. deserticola Trappe, Bloss et J.A. Menge, G. ? etunicatum W.N. Becker et Gerd., G. fasciculatum (Thaxt.) Gerd. et Trappe emend. C. Walker et Koske, G. geosporum (Nicol. et Gerd.) C. Walker, G. macrocarpum Tul. et C. Tul., G. mosseae (Nicol. et Gerd.) Gerd. et Trappe, G. pansihalos S.M. Berch et Koske, an unrecognized Glomus sp., Pacispora scintillans (S.L. Rose et Trappe) Sieverd. et Oehl, Scutellospora dipurpurescens J.B. Morton et Koske, and S. pellucida (Nicol. et N.C. Schenck) C. Walker et F.E. Sanders.

Although Am. gerdemannii probably has a worldwide distribution, this species has been infrequently reported. Most reports of $\mathrm{Am}$. gerdemannii come from the United States of America (Allen, MacMahon 1985; An et al. 1990, 1993; An, Guo and Hendrix 1993a; An, Quo and Hendrix 1993b; Bever et al. 1996; Koske, Gemma and Jackson 1977; Nicolson, Schenck 1979; Rose, Daniels and Trappe 1979). Additionally, spores of this fungus have been isolated in Brazil (Moreira-Souza et al. 2003), Colombia (Dodd et al. 1990), and Australia (Morton, Redecker 2001). In southern Poland, Turnau et al. (2001) recovered spores of a morphotype named Glomus sp. HM-CL4 of molecular properties close (71\%) to those of G. gerdemannii, the basionym of Am. gerdemannii (Walker et al. 2007). However, the authors did 
not show any morphological characters of the spores isolated and did not determine which of the two morphotypes of this fungus was found.

Mycorrhizal associations. Spores of Am. gerdemannii occurred among vesicular-arbuscular mycorrhizal roots of the plant species listed in the section "Collection examined". Additionally, they were recovered from some trap cultures established from mixtures of roots and rhizosphere soils of these plants and with $P$. lanceolata as the plant host. Unfortunately, many attempts to produce one-species cultures of Am. gerdemannii failed.

According to Morton (2002) and Morton \& Redecker (2001), mycorrhizae of Am. gerdemannii consisted of only arbuscules and intraradical hyphae; no vesicles were found. All the structures were patchily distributed along roots and stained weakly or not at all in trypan blue. Percentage mycorrhizal colonization always was very low, below $10 \%$.

Notes. Ambispora gerdemannii has originally been described as Glomus gerdemanii S.L. Rose, B.A. Daniels et Trappe from spores isolated from soils of Cascade Range and Siskiyou Mountains of Oregon, USA (Rose et al. 1979). Spain et al. (2006) transferred G. gerdemannii to the genus Appendicispora Spain, Oehl et Sieverd. gen. nov., and Walker et al. (2007) to the genus Ambispora C. Walker, Vestberg et Schuessler gen. nov. in the newly erected family Ambisporaceae C. Walker, Vestberg et Schuessler. The genus Appendicispora has been excluded because a nomenclatural error (Walker et al. 2007).

The distinctive morphological properties of Am. gerdemannii are the fragile bilayered inner wall 1 and the mode of differentiation of spores of this fungus. Additionally, Am. gerdemannii is a dimorphic fungus producing two morphotypes, acaulosporioid (as in Acaulospora spp.) and glomoid (as in Glomus spp.), a phenomenon rarely occurring in other species of arbuscular fungi.

Inner wall 1 of $A m$. gerdemannii resembles a hardened glass. In slightly crushed spores, linear cracks appear on the surface of this wall. However, in spores vigorously crushed, this wall almost always breaks into small pieces. Another characteristic of this wall is its glittering when seen in a polarized light.

When observed under a dissecting microscope, Am. gerdemannii spores may easily be confused with those of $A$. spinosa, $A$. thomii, Am. appendicula and Am. fennica. All the fungi form yellow brown and dull spores of a similar size range.

Spores of Am. appendicula, Am. fennica, and Am. gerdemannii differ mainly in the properties of layers of inner wall 1. In the latter two species, both layers of this wall are smooth on both sides (Spain et al. 2006; Walker et al. 2007). In contrast, in the former fungus, the lower surface of layer 1 is ornamented with hemispherical protuberances, which impress hemispherical concave depressions on the upper surface of layer 2 during its differentiation (Morton, Redecker 2001; Spain et al. 2006). Additionally, in vigorously crushed spores, inner wall 1 of Am. fennica and Am. gerdemannii usually disintegrates, and that of $A m$. appendicula remains its integrity. As concluded above (see comments on Am. fennica), Am. fennica and Am. gerdemannii probably are congeneric.

The subcellular structure readily separating Am. gerdemannii from $A$. spinosa and $A$. thomii is the beaded outer layer and the flexible to plastic, dextrinoid inner layer present in the innermost wall of spores of the latter two species (vs. no such structures have been found in spores of Ambispora spp.). Additionally, in Am. 
gerdemannii the sporiferous saccule wall is continuous with spore wall layers 1-3 and layer 1 of inner wall 1, whereas in all known Acaulospora spp. the sporiferous saccule wall is continuous with only spore wall layer 1 . Finally, only Am. gerdemannii is a dimorphic fungus, forming both acaulosporioid and glomoid spores. The glomoid morphotype of Am. gerdemannii has not so far been found in Poland and the only report of its existence is that of Morton and Redecker (2001).

Glomus badium Oehl, Redecker et Sieverd.

Spores occur in dense sporocarps in the soil (Fig. 9) and on the surface of vesicular-arbuscular mycorrhizal roots. Sporocarps brownish orange (6C8) to reddish brown (8E8), mainly ovoid to irregular, 200-500 × 290-680 $\mu \mathrm{m}$ (Fig. 9), sometimes globose to subglobose, (250-)298(-320) $\mu \mathrm{m}$ diam, with 4-43 spores, radially originating from a hyphal plexus (Fig. 10) and separated by an interspore mycelium (Figs 11 and 14) and occasionally by cystidium-like structures (Fig. 12). Interspore mycelium consists of tightly interwoven, straight or branched, hyaline to pale orange (5A3) hyphae, (2.2-)5.8(-12.3) $\mu \mathrm{m}$ wide, with a wall (0.5-)1.1(-1.5) $\mu \mathrm{m}$ thick (Figs 11 and 14). Cystidium-like structures icicle-like, hyaline, 32.1-39.5 $\mu \mathrm{m}$ long, 9.6-12.0 $\mu \mathrm{m}$ wide at the base, with a wall (1.8-)2.0(-2.3) $\mu \mathrm{m}$ thick (Fig. 12). Both the interspore mycelium and the cystidium-like structures branch out from the hyphal plexus. Inside sporocarps frequently with sand grains and soil debris.

Spores formed blastically at the tip of hyphae developing from a hyphal plexus positioned in the centre of sporocarps (Fig. 10). Hyphal plexus composed of thickwalled, 6.9-10.3 $\mu \mathrm{m}$ thick, two-layered hyphae: a hyaline, evanescent, 0.5-0.8 $\mu \mathrm{m}$ thick outer layer, usually highly deteriorated and difficult to see in mature spores and pale orange (5A3) to brownish orange (6C8), permanent, (1.2-)2.3(-3.4) $\mu \mathrm{m}$ thick inner layer (Fig. 12).

Spores brownish orange (6C8) to reddish brown (8E8), usually ovoid, 35-55 $\times$ 60-70 $\mu \mathrm{m}$, rarely globose to subglobose, (35-)55(-65) $\mu \mathrm{m}$, usually with one subtending hypha (Figs 9, 10 and 14-16), occasionally with two. Subcellular spore structure consists of a spore wall comprising three layers (layers 1-3; Figs 13 and 14). Layer 1 evanescent, hyaline to pale orange (5A3), (0.7-)2.0(-3.4) $\mu$ m thick, frequently highly or completely sloughed in mature spores (Figs 13 and 14). Layer 2 laminate, brownish orange (6C8) to reddish brown (8E8), (3.7-)4.5(-6.9) $\mu \mathrm{m}$ thick (Figs 13 and 14). Layer 3 flexible, pale yellow (4A3) to light brown (6D8), (0.5)1.7(-2.0) $\mu \mathrm{m}$ thick, usually tightly adherent to the lower surface of layer 2 (Figs 13 and 14). Subtending hypha brownish orange (6C8) to reddish brown (8E8), straight or recurved, cylindrical or slightly flared, rarely slightly constricted, (8.1-)9.5(-10.0) $\mu \mathrm{m}$ wide at the spore base (Figs 10, 15 and 16). Wall of subtending hypha brownish orange (6C8) to reddish brown (8E8), (2.9-)4.4(-7.4) $\mu \mathrm{m}$ thick at the spore base, continuous with spore wall layers 1 and 2 (Fig. 15). Pore 1.0-1.7 $\mu$ m wide at the spore base, occluded by spore wall layer 3 inserted in the lumen of the subtending hypha up to $14.0 \mu \mathrm{m}$ below the spore base (Fig. 14) or/and by thickening of spore wall layer 2 and wall layer 2 of subtending hypha, in which a hyphal plug occasionally forms (Fig. 16).

Collections EXAMined. Poland. Szczecin $\left(53^{\circ} 26^{\prime} \mathrm{N}, 1^{\circ} 35^{\prime} \mathrm{E}\right)$, under Glycine max (L.) Merr., 5 Sept. 1985, Btaszkowski J. 2644-2646 (DPP); Przelewice, among roots of Malus $\times$ purpurea Rehder, 16 July 1985 ,

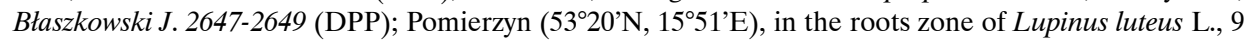
Aug. 1985, Btaszkowski J. 2650-2652 (DPP); Szczecin, in the rhizosphere soil of Anthriscus sylvestris (L.) Hoffm., 18 Oct. 1985, Btaszkowski J. 2653 (DPP); Kołbacz (53¹8’N, 14²49’E), under Trifolium pratense 
L., 4 Aug. 1985, Btaszkowski J. 2654-2655 (DPP); Szczecin, from under Allium schoenoprasum L., 3 Sept. 1985, Btaszk. J. s.n. (DPP); Międzyzdroje (5356'N, 14²6'E), among roots of Avena sativa L., 14 July 1985, Btaszk. J. s.n. (DPP); Przelewice, in the roots zone of Acer palamatum Thunb., 15 May 1985, Btaszk. J. s.n. (DPP); Żelistrzewo $\left(54^{\circ} 41^{\prime} \mathrm{N}, 18^{\circ} 27^{\prime} \mathrm{E}\right)$, under Triticum aestivum L., 24 Aug. 1985, Btaszk. J. s.n. (DPP);

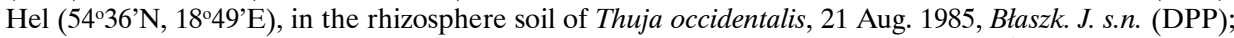
Jarosławki (53³2'N, 1501'E), under Zea mays L., 25 July 1985, Btaszk. J. s.n. (DPP); Żelistrzewo, among roots of Ficaria verna Huds., 3 April 1989, Btaszk. J. s.n. (DPP); Hel, in the root zone of T. occidentalis, 28 Sept. 1988, Błaszk. J. s.n. (DPP); Szczecin, under T. occidentalis, 18 Oct. 1985, Błaszk. J. s.n. (DPP); Żelistrzewo, near roots of Festuca ovina L., 25 June 1986, Btaszk. J. s.n. (DPP); Jastrzębia Góra (5450'N, $18^{\circ} 18^{\prime} \mathrm{E}$ ), under Crataegus monogyna Jacq., 30 Oct. 1987, Błaszk. J. s.n. (DPP); Żelistrzewo, from under

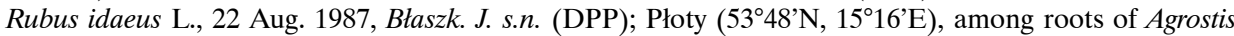
stolonifera L., 22 Sept. 1987, Btaszk. J. s.n. (DPP); Jastrzębia Góra, in the rhizosphere soil of J. communis L., Btaszk. J. s.n. (DPP); Szczecin, under Heracleum sphondylium L., 22 Oct. 1987, Btaszk. J. s.n. (DPP); Osłonino (54 $\left.42^{\prime} \mathrm{N}, 18^{\circ} 28^{\prime} \mathrm{E}\right)$, in the root zone of Helictotrichon pubescens (Huds.) Pilg., 22 June 1988, Btaszk. J. s.n. (DPP); Chałupy, among roots of Festuca arundinacea Schreb., 28 Sept. 1988, Btaszk. J. s.n. (DPP); Kuźnica (54ㄴ1N, $\left.18^{\circ} 34^{\prime} \mathrm{E}\right)$, associated with roots of Ammophila arenaria (L.) Link, 28 Sept. 1988, Btaszk. J. s.n. (DPP); Władysławowo $\left(54^{\circ} 47^{\prime} \mathrm{N}, 18^{\circ} 26^{\prime} \mathrm{E}\right)$, on roots of Rosa rugosa Thunb., 7 July 1989, Błaszk. J. s.n. (DPP); Bolesław $\left(50^{\circ} 00^{\prime} \mathrm{N}, 18^{\circ} 12^{\prime} \mathrm{E}\right)$, under an unrecognized grass, 17 Sept. 1989 , Błaszk. J. s.n. (DPP); Nowy Ujków (50 $\left.10^{\circ} \mathrm{N}, 19^{\circ} 26^{\prime} \mathrm{E}\right)$, among roots of Agropyron repens (L.) P. Beauv., 17 Sept. 1989, Btaszk. J. s.n. (DPP); Leszna Góra $\left(49^{\circ} 42^{\prime} \mathrm{N}, 18^{\circ} 43^{\prime} \mathrm{E}\right)$, associated with roots of C. monogyna,

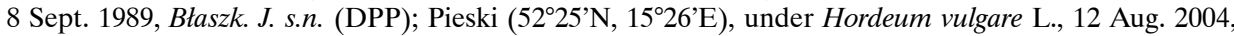
Btaszk. J. s.n. (DPP); Połupin $\left(52^{\circ} 03^{\prime} \mathrm{N}, 15^{\circ} 06^{\prime} \mathrm{E}\right)$, from under Rumex acetosella L., 12 Aug. 2004, Btaszk. J. s.n. (DPP); Jemiołów ( $52^{\circ} 21^{\prime} \mathrm{N}, 15^{\circ} 16^{\prime} \mathrm{E}$ ), in the root zone of Cirsium arvense (L.) Scop., 13 Aug. 2004,

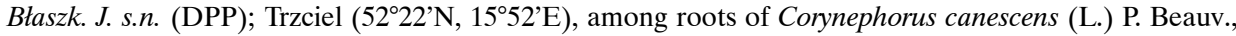

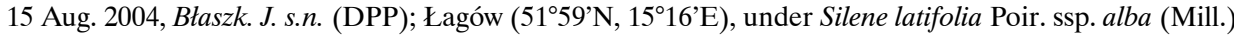
Greuter et Burdet, 13 Aug. 2004, Btaszk. J. s.n. (DPP); Jemiołów, among roots of H. perforatum, 13 Aug. 2004, Btaszk. J. s.n. (DPP); Zarzyń (52²3’ N, 15²5’E), from under E. arvense, 13 Aug. 2004, Btaszk. J. s.n. (DPP); Trzciel, in the rhizosphere soil of Juncus effusus L., 15 Aug. 2004, Btaszk. J. s.n. (DPP).

Distribution AND habitat. In Poland, G. badium was recovered from 39 fieldcollected mixtures of roots and rhizosphere soils. Of them, 15 came from under nine species of cultivated plants, and the others represented 20 species of wild plants.

The spore abundance of $G$. badium was much higher among roots of wild plants (av. 126.3; range 1-850 in $100 \mathrm{~g}$ dry soil) than cultivated plants (av. 5.2; range 1-20 in $100 \mathrm{~g}$ dry soil). The proportion of spores of this fungus in spore populations of all arbuscular fungi isolated also was higher in the root zone of wild plants (av. 45.2\%; range $0.9-100 \%$ ) than cultivated ones (av. 10.8\%; range $0.9-40.7 \%$ ). The species abundance in the root and soil samples taken from under cultivated plants averaged 5.0 with a range of 4-7 in $100 \mathrm{~g}$ dry soil, and that under wild plants averaged 3.7 and ranged from 1 to 9 in $100 \mathrm{~g}$ dry soil.

The arbuscular fungi co-occurring with $G$. badium were $A$. polonica Błaszk., $A$. capsicula, A. cavernata Błaszk., A. gedanensis Błaszk., A. lacunosa, A. mellea Spain et N.C. Schenck, $A$. paulinae, an unrecognized Acaulospora sp., G. aggregatum N.C. Schenck et S.M. Sm. emend. Koske, G. caledonium, G. constrictum, G. deserticola, G. ? etunicatum, G. fasciculatum, G. fuegianum, G. geosporum, G. microcarpum Tul. et C. Tul., G. macrocarpum, G. mosseae, unrecognized Glomus spp., Paraglomus occultum (C. Walker) J.B. Morton et D. Redecker, Scutellospora armeniaca Błaszk., and Scutellospora dipurpurescens.

Apart from Poland, G. badium has been found among roots of grasses and grassland plants growing in soils of $\mathrm{pH}$ 6-8 and located in Germany, France, Switzerland, and Italy (Oehl et al. 2005). 
Mycorrhizal ASSOCIATIONS. The sporocarps of G. badium found by the authors of this paper were formed among and occasionally on vesicular-arbuscular mycorrhizal roots of the plant species listed in the section "Collection examined". In trap cultures with root and rhizosphere soil mixtures of the plant species sampled, $G$. badium rarely produced spores. All one-species cultures of this fungus established were unsuccessful. Oehl et al. (2005) also failed to obtain G. badium in one-species cultures and, hence, properties of mycorrhizae of this fungus remain unknown. However, phylogenetic molecular analyses showed G. badium to be a member of Glomus Group A (Oehl et al. 2005) sensu Schwarzott, Walker and Schüßler (2001), comprising fungi known to form vesicular-arbuscular mycorrhizae (Błaszkowski 2003).

The most distinguishing characters of $G$. badium are its small sporocarps lacking a peridium and composed of many, brownish orange to reddish brown, relatively small spores (Fig. 9). The innermost flexible to semi-flexible and coloured layer of the threelayered spore wall also is a diagnostic property of this species (Figs 13 and 14).

Glomus badium probably forms spores only in multispored sporocarps, and single spores occasionally recovered from field-collected soil samples represented their fragments. Examination of the ontogenesis of this species is needed to confirm this supposition. Unfortunately, all attempts to produce one-species cultures of $G$. $b a$ dium made by the authors of this paper and by Oehl et al. (2005) failed.

The interspore mycelium of the specimens of G. badium found by the authors of this paper morphologically corresponds to that characterized by Oehl et al. (2005). However, the original description of this fungus does not inform of the cystidiumlike structures occurring between spores of the Polish sporocarps of this fungus. The function of the cystidia-like structures in sporocarps of G. badium probably is similar to that of cystida of Agaricales, in which they appear to serve as spacers between basidia (Ulloa, Hanlin 2000).

Of the three wall layers of spores of G. badium, the two outer ones are typical of most species of the genus Glomus, in which the outermost layer sloughs with age and adheres to a laminate structural layer (Figs 13 and 14). Spore wall layer 3 of $G$. badium is thin, pale yellow (4A3) to light brown (6D8), and usually tightly adheres to the lower surface of the brownish orange (6C8) to reddish brown (8E8) layer 2 in even vigorously crushed spores (Figs 13 and 14). Hence, it is difficult to see, especially in young and freshly matured spores. In older spores, this layer usually is slightly thicker and more frequently separates from the middle laminate layer. Additionally, this layer is most visible at the spore base where it forms a straight or curved septum of the subtending hypha continuous with its part adherent to the laminate spore wall layer 2 (Fig. 14).

Apart from G. badium, species of the genus Glomus forming small and compact sporocarps with small, brownish orange to reddish brown spores are G. cuneatum McGee et Cooper, G. fuegianum (Speg.) Trappe et Gerd., G. invermaium I.R. Hall, and G. rubiforme (Gerd. et Trappe) R.T. Almeida et N.C. Schenck. Compared with G. badium, sporocarps of G. cuneatum are much larger (2-12 mm vs. 200-500 × 290$680 \mu \mathrm{m}$ in G. badium) and have a peridium (Fig. 9; vs. no peridium in G. badium; McGee and Trappe 2002). Additionally, the spore wall of the latter species consists of only one laminate layer lightening from black to hyaline towards their inside, whereas the spore wall of the former fungus comprises three layers, of which the laminate layer is dark- and uniform-coloured (Figs 10, 12 and 16). 
According to Thaxter (1922), G. fuegianum spores coming from Spegazzini's original collection were reddish brown as are those of $G$. badium. In contrast, all G. fuegianum spores found by one of the authors (J. B.) of this paper in Poland, those loaned from Kew, United Kingdom (Błaszkowski, Madej and Tadych 1998), and those revealed in Australia by McGee and Trappe (2002) were pale yellow to yellow brown. Moreover, the spores were frequently surrounded by branched and convoluted hyphae (Błaszkowski 2003) that never occur on G. badium spores (Błaszkowski, pers. observ.; Oehl et al. 2005). Finally, the radial arrangement of spores in sporocarps of G. fuegianum is regular, and irregular in G. badium sporocarps.

Glomus badium differs from $G$. invermaium in the formation of smaller $(200-500 \times 290-680 \mu \mathrm{m}$ vs. up to $1 \mathrm{~mm}$ across $)$ and more compact sporocarps with regularly distributed spores (Fig. 9; vs. loose sporocarps with randomly distributed spores in G. invermaium; Błaszkowski, pers. observ.; Hall 1977). Other differences are the number and the phenotypic properties of the spore wall layers of these fungi. The spore wall of $G$. badium comprises three layers, of which the outermost one sloughs with age (Figs 13 and 14). In contrast, the outermost spore wall layer of G. invermaium spores is persistent and the spore wall of this species lacks spore wall layer 3 of $G$. badium.

The main difference between $G$. badium and G. rubiforme resides in the wall structure of their spores. The spore wall of $G$. rubiforme comprises only two layers similar in colour and phenotypic properties to layers 1 and 2 of the spore wall of G. badium (Błaszkowski 2003; Gerdemann, Trappe 1974).

Acknowledgment. This study was supported in part by the Committee of Scientific Researches, a grant no. 2 PO4C 04128 and 164/N-COST/2008/0.

\section{REFERENCES}

Allen M. F., MacMahon J. A. 1985. Impact of disturbance on cold desert fungi: comparative microscale dispersion patterns. Pedobiologia 28: 215-224.

An Z.-Q., Grove J. H., Hendrix J. W., Hershman D. E., Henson G. T. 1990. Vertical distribution of endogonaceous mycorrhizal fungi associated with soybean as affected by soil fumigation. Soil Biol. Biochem. 22: 715-719.

An Z.-Q., Guo B. Z., Hendrix J. W. 1993. Mycorrhizal pathogen of tobacco: cropping history and current crop effects on the mycorrhizal fungal community. Crop prot. 12: 527-531.

An Z.-Q., Hendrix J. W., Hershamn D. E., Ferriss R. S., Henson G. T. 1993 . The influence of crop rotation and soil fumigation on a mycorrhizal fungal community associated with soybean. Mycorrhiza 3: 171-182.

An Z. Q., Quo B. Z., Hendrix J. W. 1993. Populations of spores and propagules of mycorrhizal fungi in relation to the life cycles of tall fescue and tobacco. Soil Biol. Biochem. 25: 813-817.

Bever J., Morton J. B., Antonovics J., Schultz P. A. 1996. Host-dependent sporulation and species diversity of arbuscular mycorrhizal fungi in a mown grassland. J. Ecol. 84: 71-82.

Błaszkowski J. 2003. Arbuscular mycorrhizal fungi (Glomeromycota), Endogone and Complexipes species deposited in the Department of Plant Pathology, University of Agriculture in Szczecin, Poland. http://www.agro.ar.szczecin.pl/ jblaszkowski/.

Błaszkowski J., Czerniawska B. 2005. Entrophospora schenckii and Pacispora franciscana, arbuscular mycorrhizal fungi (Glomeromycota) new for Europe and Poland, respectively. Acta Mycol. 40 (1): $11-18$.

Błaszkowski J., Madej T., Tadych M. 1998. Entrophospora baltica sp. nov. and Glomus fuegianum, two species in the Glomales from Poland. Mycotaxon 68: 165-184.

Błaszkowski J., Tadych M., Madej T., Adamska I., Czerniawska B., Iwaniuk A. 1999. Acaulospora mellea and A. trappei, fungi new for Poland. Acta Mycol. 34 (1): 41-50. 
Dodd J. C., Arias I., Koomen I., Hayman D. S. 1990. The management of populations of vesicualr-arbuscular mycorrhizal fungi in acid-infertile soils of a savanna ecosystem. Plant and Soil 122: 241-247.

Gerdemann J. W., Trappe J. M. 1974. The Endogonaceae in the Pacific Northwest. Mycological Memoir 5: $1-76$.

Hall I. R. 1977. Species and mycorrhizal infections of New Zealand Endogonaceae. Trans. Brit. Mycol. Soc. 68: 341-356.

Koske R. E., Gemma J. N., Jackson N. 1977. Mycorrhizal fungi associated with three species of turfgrass. Can. J. Bot. 75: 320-332.

McGee P. A., Trappe J. M. 2002. The Australian zygomycetous mycorrhizal fungi. II. Further Australian sporocarpic Glomaceae. Austral. Syst. Bot. 15: 115-124.

Moreira-Souza M., Trufem F. B., Gomes-da-Costa S. M., Cardoso E. J. B. N. 2003. Arbuscular mycorrhizal fungi associated with Araucaria angustifolia (Bert.) O. Ktze. Mycorrhiza 13: 211-215.

Morton J. B. 2002. International Culture Collection of (Vesicular) Arbuscular Mycorrhizal Fungi. West Virginia University: http://www.invam.caf.wvu.edu/.

Morton J. B., Redecker D. 2001. Two families of Glomales, Archaeosporaceae and Paraglomaceae, with two new genera Archaeospora and Paraglomus, based on concordant molecular and morphological characters. Mycologia 93: 181-195.

Nicolson T. H., Schenck N. C. 1979. Endogonaceous mycorrhizal endophytes in Florida. Mycologia 71: 178-198.

Oehl F., Redecker D., Sieverding E. 2005. Glomus badium, a new sporocarpic mycorrhizal fungal species from European grasslands with higher soil pH. J. Appl. Bot. and Food Qual. 79: 38-43.

Omar M. B., Bollan L., Heather W. A. 1979. A permanent mounting medium for fungi. Bull. Brit. Mycol. Soc. 13: 31-32.

Rose S., Daniels B. A., Trappe J. M. 1979. Glomus gerdemannii sp. nov. Mycotaxon 8: 297-301.

Schwarzott D., Walker C., Schüßler A. 2001. Glomus, the largest genus of the arbuscular mycorrhizal fungi (Glomales) is nonmonophyletic. Mol. Phylogen. Evol. 21: 190-197.

Spain J. L., Sieverding E., Oehl F. 2006. Appendicispora: a new genus in the arbuscular mycorrhiza-forming Glomeromycetes, with a discussion of the genus Archaeospora. Mycotaxon 97: 163-182.

Thaxter R. 1922. A revision of the Endogonaceae. Proc. Am. Acad. Arts and Sci. 57: 291-351.

Turnau K., Ryszka P., Gianinazzi-Pearson V., Tuinen D. van 2001. Identification of arbuscular mycorrhizal fungi in soils and roots of plants colonizing zinc wastes in southern Poland. Mycorrhiza 10: $169-174$.

Ulloa M., Hanlin R. T. 2000. Illustrated Dictionary of Mycology. APS Press. The American Phytopathological Society. St. Paul, Minnesota.

Walker C., Vestberg M., Demircik F., Stockinger H., Saito M., Sawaki H., Nishmura I., Schüßler A. 2007. Molecular phylogeny and new taxa in the Archaeosporales (Glomeromycota): Ambispora fennica gen. sp. nov., Ambisporaceae fam. nov., and emendation of Archaeospora and Archaeosporaceae. Mycol. Res. 111: 137-153.

\section{Ambispora gerdemannii and Glomus badium, dwa gatunki grzybów arbuskularnych (Glomeromycota) nowe odpowiednio dla Europy i Polski}

\section{Streszczenie}

Opisano i zilustrowano cechy morfologiczne zarodników oraz sporokarpów i zarodników odpowiednio Ambispora gerdemannii i Glomus badium, grzybów arbuskularnych z gromady Glomeromycota. Ponadto przedstawiono poznane rozmieszczenie tych gatunków zarówno w Polsce, jak i innych regionach świata. Ambispora gerdemannii nie była dotychczas notowana w Europie, a G. badium jest nowym grzybem dla Polski. 